\title{
Research on the Young Athletes Training Method Based on the Individual Characteristics
}

\author{
Wen-Jun Niu*
}

P.E. Department, Zhejiang University of Science and Technology, Hang Zhou, Zhe Jiang, China

\begin{abstract}
In recent years, the concept stratified teaching is popular and accepted by most physical education teachers step by step. Just as its name implies, stratified teaching means carrying out targeted teaching activities according to each student's characteristics. In physical education, the teacher must face the differences and train the athlete according to their individual characteristics.
\end{abstract}

Keywords: Elite athletes, individual characteristics, training method.

\section{INTRODUCTION}

Recently, there is a heated discussion about cultivating the talents according to their individual characteristics in the education field [1-3]. As a practical activity of education field, competitive sports haven't got much attention as other subjects. Few scholars have studied the topic of training the high-level athletes according to their characteristics. The appearance of the new teaching concept - stratified teaching has got great attentions of the educators, especially the physical teacher.

In this paper, the author will introduce what is stratified teaching first. Next, we will discuss the significance of applying this teaching mode in physical education [4-6]. Then, we will explore the methods of training the athletes based on their individual characteristics.

\section{THE DEFINITION OF STRATIFIED TEACHING}

The modern physical teaching stresses the differences and demands of each student. It advocates and encourages the students to explore and practice in exercise. So how can we focus on the differences and demands of each student to make each student get effective exercise and development? The author will solve this problem by exploring the stratified teaching pattern. Stratified teaching refers to that the physical teacher divides the teaching content into different degree; then the student so exercise according to his own ability [79]. Besides, the student can freely choose their own methods of exercise based on his interest and level. When he has finished the easy task, he can do the highly difficult exercise. It is believed that this method can not only increase the student's interest of study, but also build a relaxed and happy learning atmosphere.

\section{THE BASIS OF PHYSICAL STRATIFIED TEACH- ING}

3.1. It Conforms to the Thought of Teaching Students According to Their Aptitude

The concept of teaching students according to their aptitude is put forward by Confucius. In the educational history, it has played an important role in cultivating talents. Nowadays, the class teaching has replaced the individual teaching and become the leading teaching pattern. To satisfy the development requirement of people and society is an important research project of the modern education. It is also our country's excellent educational tradition. In physical teaching, the students come from different regions and schools. They have accepted different physical education. Besides, their physical quality and athletic ability have great differences. Therefore, stratified teaching meets the needs of the development of students' body and mind. It also conforms to the physical teaching principles

\subsection{It Conforms to the Acceptable Principle and Learn- ing Strategy}

The famous education practice theorists Johann Amos Comenius once said: "the knowledge imparted must conform to the youth age and mentality. All the courses must suit the student's competence." The stratified teaching pattern provides the students with suitable learning environment and conditions according to his different athletic competence and individual characteristics. Besides, it gives help to increase the student's physical learning competence. Thus, the athlete can control his learning effect and degree. These completely meet the physical teaching acceptable principle and learning strategy.

\subsection{It Conforms to the Students' Physical and Mental Development}

In the process of the student's physical and mental development, the students' personality, physical state, interest and 
competence are different for the influence of inheritance, family, society, education, physical training and so on. According to these differences, the stratified teaching pattern adapts suitable methods to train each student so as to meet the student's development demands.

\subsection{It Conforms to the School's Educational Concept of "Encourage Talents"}

The famous professor Lin Chongde once put forward the concept "encourage the students to stand out", "allow the students to fall behind". These fully prove that the stratified teaching in physical education conforms to the educational concept of "encourage talents". The physical education proposes the concept of "train the students to be a useful person; train the students to be a excellent person; train the students to be a special talent" according to their individual characteristics and physical competence.

\subsection{The Methods of Training Athletes According to Their Individual Characteristics}

In last part, we have discussed the basis of the physical stratified teaching. Now, let's talk about the methods of how training athletes according to their individual characteristics.

\subsection{The Physical Teaching Goals Must be Scientific}

Before the physical teacher lays down the teaching goal, he must delve into the P.E. teaching materials and choose the teaching content elaborately. Besides, he must fully know about and analyze each athlete's actual level. Based on the existing teaching conditions of school, the teacher can divide the teaching goals into the basic goal that all the athletes can grasp, the middle-level goal that most of the athletes can master, the developing goal that the high-level athletes can mater. The division makes the physical teaching goals more targeted and scientific. In other words, they are more objective and measurable.

\subsection{The Study Level Must be Objective}

The teacher should divide the athletes into different levels according to their original athletic ability, interest, learn- ing method and receptivity. So it is necessary for the teacher to know about and analyze the students' actual conditions objectively. Of course, the division of levels is not invariable. The teacher must adjust the teaching goal and content in time according to the student's learning conditions so as to satisfy the student's development demands.

\subsection{The Teaching Methods Must be Flexible}

We should apply different teaching methods according to different levels. For the basic-level students, they should start with simple actions. The teacher should lower the demand and slow down the teaching speed. Thus, let the students familiar to the basic physical knowledge and technique. For the middle-level students, the teacher should pay more attention to consolidate the knowledge and technique that the students have learned, and improve the demand. For the high-level students, the teacher should tend to deepen the difficulty and demand, which is good to unlock the students' potential.

\subsection{The Individual Tuition and Communication Must be Effective}

The students' ability can be improved through individual tuition. For the common problems, the teacher can tutor the whole class at the same time. For the individual problems, the teacher should tutor the student according to his aptitude. In these processes, the teacher must present briefly and succinctly. Besides, he should demonstrate normatively. The students must listen carefully, look concentratedly and exercise hardly. Besides, they should learn and exercise initiatively. For the contents that cannot complete at class, the students must exercise positively. In addition, they must do exercise repeatedly in order to ensure the effect. The communication between the teacher and students is very important. The efficient communication is the key to the realization of the teaching goals.

In summary, to improve the students' physical ability, the teacher must face the differences positively and carry out individual teaching. It is necessary for the teacher to admit
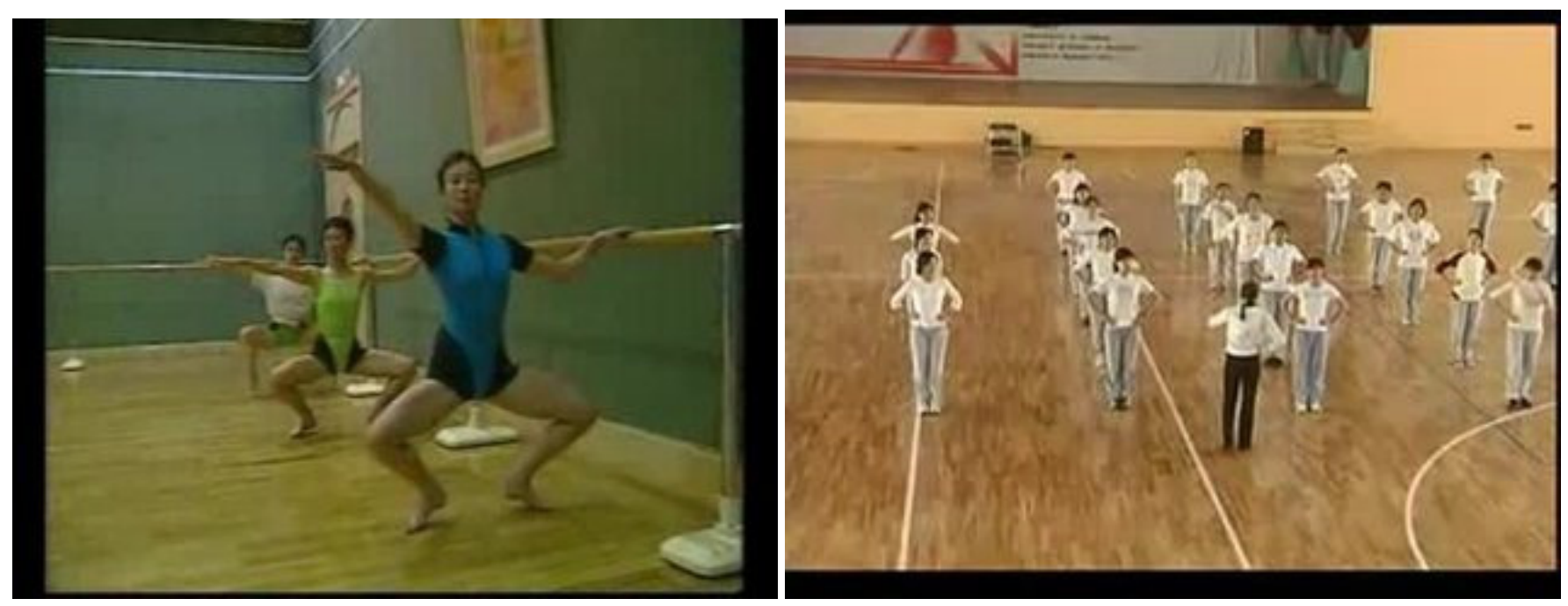

Fig. (1). The teaching of aerobics. 
and stress the difference, then arrange teaching plans. So the stratified teaching pattern is the core of the physical teaching. In the teaching process, we need make teaching goals according to the new curriculum standards. For example, when we learn the aerobics, the three-dimensional teaching target is to shape a good figure, improve the students' aesthetic taste and build the habit of lifelong exercise. The difficult point is the rhythrn sensation and harmony. The difficult point is to memorize all the actions. In the class, the teacher should explain each action and the matters needed attention in detail. When all the students warm up, the teacher divides the students into three levels according to their physical attribute and mastery degree of the actions. Then the teacher put out different goals for each group.

In this way, each level of students can taste the fruits of success and become more confident. Thus, the students can keep the positive condition of study and exercise. To cultivate the students' spirit of hard-working and innovation is most important in teaching.

\section{CONCLUSION}

In a word, it is a fact that there are differences in each subject teaching. The differences are more obvious in physical teaching for the influence of physical conditions. So the teacher must analyze each student's physical condition and ability then make targeted teaching plan. By accepting differences to make up the differences conforms to the modern teaching concept.

\section{CONFLICT OF INTEREST}

The author confirms that this article content has no conflict of interest.

\section{ACKNOWLEDGEMENTS}

Declared none.

\section{REFERENCES}

[1] Y. M. Wang, "The practice of stratified teaching in physical education," Journal of Shan xi Education, vol. 2, no. 1, pp. 32-44, 2009.

[2] Y. W. Liu and Y. Dong, "Analysis of the origin and value of the concept of teaching students according to their aptitude," China Electric Power Education, vol. 21, no. 6, pp. 3-4, 2012.

[3] Y. L. Li, "The teaching method of teaching students according to their aptitude," Higher Education Exploration, vol. 12, no. 3, pp. 12-14, 2012.

[4] C. D. Lin, "Cultivate the adorable students," University Education Science, vol. 12, no. 3, pp. 31-39, 2010.

[5] Y. Guo and Y. D. Wei, "Analysis of the physical stratified method," Journal of Beijing Sport University, vol. 29, no. 3, pp. 210, 2011.

[6] W. G. Wu, "Building the modern individualized teaching process management," Shanghai Education, vol. 22, no. 1, pp. 42-50, 2007.

[7] B.J. Maron, "Recommendations for physical activity and recreational sports participation for young patients with genetic cardiovascular diseases." Circulation, vol. 109, no. 22, pp. 2807-2816, 2004.

[8] G. W. Heath, "A physiological comparison of young and older endurance athletes." Journal of Applied Physiology, vol. 51, no. 3, pp. $634-640,1981$

[9] A. Baxter-Jones, H. Goldstein, and P. Helms. "The development of aerobic power in young athletes." Journal of Applied Physiology, vol. 75 , no. 3, pp. 1160-1167, 1993.

Received: June 10, 2015

Revised: July 29, 2015

Accepted: August 15, 2015

(C) Wen-Jun Niu; Licensee Bentham Open.

This is an open access article licensed under the terms of the (https://creativecommons.org/licenses/by/4.0/legalcode), which permits unrestricted, noncommercial use, distribution and reproduction in any medium, provided the work is properly cited. 